\title{
A Haldane perspective from a Fisher student
}

\author{
W. F. BODMER* \\ Weatherall Institute of Molecular Medicine and Department of Oncology, University of Oxford, Oxford, UK OX3 9DS, UK \\ *E-mail: walter.bodmer@hertford.ox.ac.uk.
}

Published online 24 November 2017

Keywords. blood groups; human genetics; population genetics; natural and artificial selection.

\section{Introduction}

J. B. S. Haldane, with R. A. Fisher and Sewall Wright, was one of the three great founders of population genetics, the field that put the study of evolution on a firm mathematical basis. Based on the assumption of Mendelian inheritance, it contributed to the reconciliation of Darwin's evolution by natural selection with genetics as described by Mendel. I was one of R. A. Fisher's last students and got to know Sewall Wright quite well in his later years, but only met Haldane two or three times. The last time was at the International Congress of Genetics in The Hague in 1963, the year before he died. He was the centre of attention, dressed in flowing white Indian robes. He spent the last seven years of his life in India and is enormously appreciated there for what he did for science, especially for his support for young scientists. This was made clear to me when I spoke at the J. B. S. Haldane Memorial Symposium in Bhubaneswar, where he spent his last few years.

\section{The Haldane Fisher relationship}

It has mostly been assumed that there was strong antagonism between Fisher and Haldane, as I once saw personally when Haldane walked ostentatiously out of a lecture being given by Fisher. It was clearly not the case that there was such mutual antagonism earlier in their careers. Haldane, for example, when he was Professor of Genetics at University College London, was instrumental in getting Fisher to the Galton Chair there in 1933. Fisher actually wrote to Haldane thanking him for his help and said that he would accept 'as soon as I can find your registrar's letter on the subject' (Box 1978, p. 259). Also it was Haldane who, in 1930, had called Fisher's attention to the genetical interest of serological studies being done by Todd (1930), and this stimulated Fisher's subsequent very considerable contribution to the development of work on the human blood groups in the UK. This was helped by a Medical Research Council committee on Human Genetics, of which Fisher was a member and Haldane its chairman. In a letter to Leonard Darwin in 1932 commenting on his relationship with Haldane, Fisher wrote 'I am on quite civil terms at present: he is chairman of a Committee on Human Genetics of the Medical Research Council, of which Hogben and self are other members' (Bennett 1983, p. 151).

I, especially, remember a UK Genetical Society meeting in 1957 at which Haldane had given a lecture, on what became one of his classical works, on 'The cost of natural selection' (Haldane 1957). I was standing in a group around R. A. Fisher, when geneticist George Dawson said, no doubt to flatter Fisher, 'Who else is there in population genetics but you?' Fisher replied, with a twinkle in his eye 'Well there is Haldane you know!'. I suspect that their outward mutual antagonism was a sort of game of peers, underlying which was a considerable respect for each other's abilities.

\section{Blood groups}

Haldane often influenced people and their science in ways that are not reflected in his published work. An example of this was his making Fisher aware of the genetic potential for serological studies, as already mentioned. Another major example was his stimulation of Peter Gorer to do his studies on mouse blood groups, which led to the discovery of the H-2 histocompatibility system in mice. Gorer (1936, 1938) acknowledges Haldane in his first two key papers published in 1936 and 1938. H-2 was the precursor of the 
human HLA tissue typing system, which is the basis for matching donors and recipients for transplantation and is now known to play a major role in the functioning of the adaptive immune system. Had Gorer not died at the young age of 54 from lung disease, almost certainly because of his smoking, he surely would have shared the Nobel Prize (with Snell and Dausset) for his discovery of H-2.

Haldane himself made one early contribution to human blood group research that is not generally as well known as his many other contributions to human genetics, namely an analysis of the distribution of the ABO blood groups in Europe (Haldane 1940). After an extensive theoretical analysis of how to estimate and plot the frequencies of the genes for $\mathrm{A}, \mathrm{B}$ and $\mathrm{O}$, he described how he took great care with the data to get whole numbers when he had to multiply percentages by 100 . He wrote: 'This is sometimes easy, but sometimes impossible, as in the case of Dabacan (1937) (who) makes the truly remarkable assertion that of 100 Turks examined at Ankara, 9.3 per cent belong to group B. I need not say that I have rejected data of this type.' He discusses the gradient of the frequency of B from East to West, comments on the variation in the frequencies of $\mathrm{A}$ and $\mathrm{O}$ 'among the peripheral populations of Western Europe' and concludes that admixture between different populations may be the explanation for these frequency patterns and, in particular, that "populations with low B are regarded as remnants of a primitive European population'. This interpretation inevitably suffers from the problem of having had only one polymorphism to characterize the genetic variation between different populations.

In discussing the distribution of some phenotypes that he assumes have a genetic basis, he comes up with the suggestion: 'There is good reason to think that the south to north gradient of pigmentation is adaptive, dense pigmentation giving protection against sunburn, but increasing the liability to rickets when sunshine is deficient. If so, there will be appreciable selection in favour of a given average pigmentation in any particular climatic zone, and provided that a fair range of genes determining colour are available, evolution may be fairly rapid.' This was a very perceptive analysis and probably the first time such ideas on the basis of the south to north gradients in human skin pigmentation were clearly articulated.

\section{'A mathematical theory of natural and artificial selection'}

Haldane is probably best known for his series of papers with this title, summarized in the appendix to his most famous book, The causes of evolution (Haldane 1932). His opening sentence in the first paper of the series, in the Proceedings of the Cambridge Philosophical Society (Haldane 1924), states: 'A satisfactory theory of natural selection must be quantitative'. It is coupling this with the Mendelian basis of the mode of inheritance that identifies
Haldane as one of the founders of population genetics. The importance and range of Haldane's contributions to human population genetics are well indicated by the fact that in the book The genetics of human populations by Cavalli-Sforza and I published in 1971, the number of pages on which Haldane is cited is (apart from the authors) second only to R. A. Fisher (Cavalli-Sforza and Bodmer 1971).

Haldane's main theoretical contributions include:

(i) The first analysis of the relationship between the recombination fraction and genetic distance.

(ii) Calculating the number of generations needed for a given increase in the frequency of a new mutation.

(iii) The estimation of mutation rates using population data.

(iv) Segregation analysis of family data and the estimation of linkage.

(v) The effect of variation on fitness and the cost of natural selection, underlying the concept of the genetic load.

(vi) The analysis of sex-linked and three-allele polymorphisms, and polymorphism due to varying directions of selection (with Jayakar).

\section{Many other stimulating ideas}

In addition to his formal theoretical and statistical contributions, Haldane was a source of many stimulating and original suggestions, often not published in conventional scientific journals. Perhaps his most famous suggestion, based on a parallel between the distribution of the inherited anaemia, thalassaemia, and the distribution of malaria, was that thalassaemia might be maintained in the population by preferential survival of the heterozygote against malaria (Haldane 1949). This idea was subsequently extended to many other polymorphisms that involve red blood cells in malarial areas, notably sickle cell anaemia, and it has received direct experimental support.

In a popular magazine article on population genetics (Haldane 1955), he introduced the idea that 'in such small populations natural selection would favour the spread of genes making for certain kinds of altruistic behaviour'. This suggestion, and a similar comment by Fisher buried in a chapter on mimicry in The genetical theory of natural selection (Fisher 1930), his famous counterpart to Haldane's Causes of evolution, laid the basis for Hamilton's later development of the notion of inclusive fitness (Hamilton 1964).

Haldane's 1946 article 'The interaction of nature and nurture' was a very perceptive discussion of the way to consider how to analyse the interaction between genetic and environmental effects. He was the first, with Oparin, to suggest how life could have evolved from certain types of chemical reactions (see article by Tirard 2017). In a review article (Haldane 1933) in Nature on the 
genetics of cancer, Haldane wrote 'The theory has been held by Boveri, Strong and others that the difference between a cancer and a normal cell is of the same character as that between the cells of two different varieties, that is to say due to chromosomal aberration or gene mutation'. This was in fact a very forward-looking extension of Boveri's discussion of chromosomal changes in cancers.

A little known suggestion made by Haldane in one of the essays in his (Haldane 1927) collection Possible worlds and other essays was how, in future, genetic marker linkage could be used to predict the inheritance of common traits or diseases. 'Now, if we had about fifty such characters', he wrote, 'instead of just two, we could use them, by a method worked out on flies by Morgan of New York and his associates, as landmarks for the study of such characters as musical ability, obesity, and bad temper'. These ideas were discussed more specifically in relation to inherited diseases by Haldane in his 1934 Norman Lockyer Lecture and by Fisher in a talk at the 1935 International Congress of Life Assurance Medicine. The ideas were brought into practice by the discovery of HLA and disease associations, and underlie the approach to studying the inherited components of complex diseases using Genome Wide Association Analysis (GWAS see e.g., Bodmer and Bonilla 2008).

\section{Two enigmas}

It has always puzzled me that Haldane, the outstanding biochemist and world renowned geneticist, did not really embrace the revolution of genetics that came with the Watson and Crick structure of DNA. His book, 'The biochemistry of genetics' was written in 1952 but published in 1954 (Haldane 1954), after the Watson Crick 1953 publication. Avery, Macleod and McCarty's famous 1944 paper showing that the bacterial transforming principle was DNA is quoted, but Haldane seems quite equivocal about the relationships among chromosomes, DNA, proteins and genes.

Haldane was, as is well known, a staunch communist and published many popular articles on science in the communist newspaper The Daily Worker. No doubt that is why he seemed to remain equivocal about Lysenko (see article by deJong-Lambert 2017). But it does seem strange that his political views were so strong even when they came in direct conflict with his science. At least he did not write the book Lysenko is right. That was left to James Fyfe, the geneticist husband of the librarian in Fisher's department of genetics in Cambridge. Fisher was surely a committed conservative, at least with a small c. No doubt Fisher and Haldane's differences in political outlook did not help their personal relationship. It is, however, intriguing to me that Fisher on the right, and Haldane and Muller on the left, were all equally committed eugenicists.

\section{Epilogue}

There is no doubt that Haldane was an extraordinary individual. His more or less complete-recall memory no doubt contributed to his very wide-ranging scientific and other interests. He had a lively writing style which was well expressed in his writings for the general reader. 'Einstein', he once said, 'was the greatest Jew since Jesus'. When asked about his view of the creator, he replied that if God exists 'He must have been fond of beetles'. In the chapter 'Science and politics' in Possible worlds and other essays published in 1927 he wrote: 'Sometimes I fear I have answered that politics are no occupation for an honest man. If I made that answer I was wrong, for it is my duty, and everyone's duty, to try to alter that state of affairs if it exists.' If only more people took that attitude to their duties! Not long before Haldane died he said, 'When I am dead, I propose to be dissected; in fact, a distinguished anatomist has already been promised my head should he survive me', and he did leave his body for dissection.

Haldane was clearly a very able mathematician whose theoretical and statistical papers were largely directed at solving or elucidating particular problems, but he did not quite have the flair that Fisher had in tackling broader issues such as in Fisher's 'Fundamental theorem of natural selection'. On the other hand, Haldane probably had the greater biological insight, which perhaps too often was buried in publications that were not, and still are not, readily accessible to the interested reader. Both were undoubtedly among the greatest and most original scientists of the twentieth century.

\section{References}

Bennett J. H.1983 (ed.) Natural selection. Heredity and Eugenics, pp. 306. Clarendon Press, Oxford.

Bodmer W. and Bonilla C. 2008 Common and rare variants in multifactorial susceptibility to common diseases. Nat. Genet. 40, 695-701.

Box, Joan Fisher 1978 R. A. Fisher, the life of a scientist, pp. 512. John Wiley, New York.

Cavalli-Sforza L. L. and Bodmer W. F. 1971 The genetics of human populations. Freeman, New York.

deJong-Lambert 2017 J. B. S. Haldane and Лысенковщина (Lysenkovschina). J. Genet. 96, (https://doi.org/10.1007/ s12041-017-0843-2).

Fisher R. A. 1930 The genetical theory of natural selection. Oxford University Press, Oxford.

Fisher R. A. 1935 Linkage studies and the prognosis of hereditary ailments. International Congress of Life Assurance Medicine, London, UK.

Gorer P. A. 1936 The detection of antigenic differences in mouse erythrocytes by the employment of immune sera. Br. J. Exp. Pathol. 17, 42-50.

Gorer P. A. 1938 The antigenic basis of tumour transplantation. J. Path. 47, 231-252.

Haldane J. B. S. 1924 A mathematical theory of natural and artificial selection. Proc. Cambridge Phil. Soc. 23, 19-41. 
Haldane J. B. S. 1927 Possible worlds and other essays. Chatto and Windus, London.

Haldane J. B. S. 1932 The causes of evolution. Longman's Green. New York, London and Toronto.

Haldane J. B. S. 1933 The genetics of cancer. Nature 132, 265-267.

Haldane J. B. S. 1934 Human biology and politics. Norman Lockyer Lecture, The British Science Guild.

Haldane J. B. S. 1940 The blood-group frequencies of European peoples and racial origins. Hum. Biol. 12, 457-480.

Haldane J. B. S. 1946 The interaction of nature and nurture. Ann. Eugen. 13, 197-205.

Haldane J. B. S. 1949 The rate of mutation of human genes. Hereditas 35, 267-273.
Haldane J. B. S. 1954 The biochemistry of genetics. George Allen, London.

Haldane J. B. S. 1955 Population genetics. New Biol. 18, 34 51.

Haldane J. B. S. 1957 The cost of natural selection. J. Genet. 55, $511-524$

Hamilton W. D. 1964 The genetical evolution of social behaviour I. J. Theor. Biol.7, 1-16.

Tirard S. 2017 J. B. S. Haldane and the origin of life. J. Genet.96, (https://doi.org/10.1007/s12041-017-0831-6).

Todd C. 1930 Cellular individuality in the higher animals, with special reference to the individuality of the red blood corpuscles. Proc. R. Soc. London, B106, 20-44.

Further relevant references to Haldane's publications can be found in his book The causes of evolution and in The genetics of human populations by L. L. Cavalli-Sforza and W. F. Bodmer. 